\title{
Treatment of combined coffee processing wastewater using constructed wetland/Cyperus-ustulatus and Typha-latifolia plants process
}

\author{
Samuel Z.A.* \\ Jimma University, Jimma Institute of Technology, Faculty of Civil and Environmental Engineering, Ethiopia \\ Received: 28/04/2021, Accepted: 21/10/2021, Available online: 30/10/2021 \\ *to whom all correspondence should be addressed: e-mail: zerihunasmelash2009@gmail.com \\ https://doi.org/10.30955/gnj.003688
}

\section{Graphical abstract}

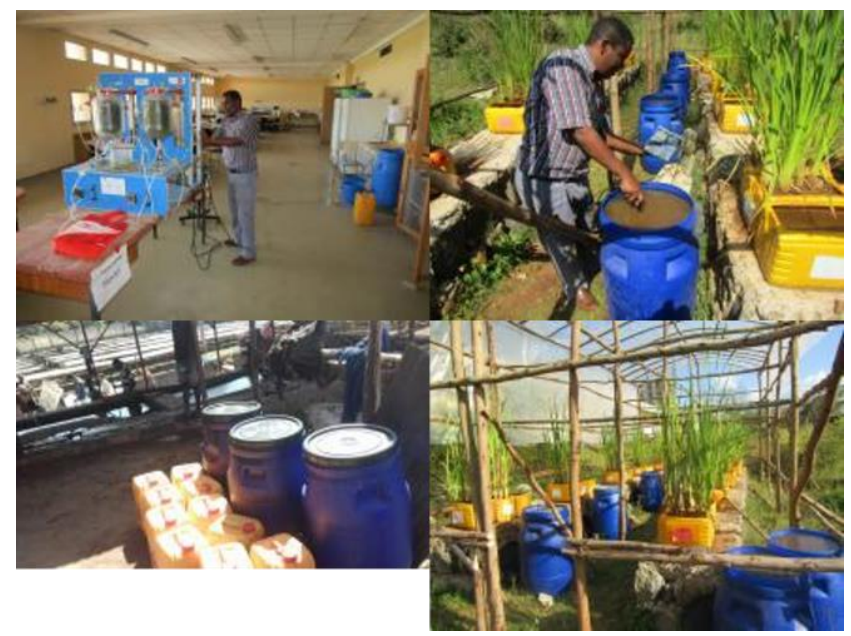

\section{Abstract}

This research investigated wastewater discharges from wet coffee processing plant (WCPP) combined with tap water (TW) treated by using Cyperus-ustulatus plant (P1), Typhalatifolia plant (P2) wetland. The WCPP wastewater was conducted by different combination of treatments (i.e. $100 \% W W+0 \%$ TW; 75\% WW + 25\% TW; 50\% WW + 50\% TW; 75\%WW + 25\% TW and 0\% WW + 100\% TW) after being irrigated for 21 days in the constructed wetland with P1, P2and control (without a plant). The highest value of total solids, chemical oxygen demand and biochemical oxygen demand increases were 76\%, 95\% and, 96\%, respectively, removed wastewater treated by $\mathrm{T3}$ ( $50 \% \mathrm{WW}$ $+50 \%$ TW) with P2 wetland after 21 days irrigated. As a result, the combination of coffee wastewater with constructed wetland treatment methods was a low-cost, affordable, technically viable and eco-friendly treatment option for the wet coffee processing plant wastewater.

Key Words: Combination, constructed wetland, coffee processing wastewater, removal capacity, wastewater treatment.

\section{Introduction}

Coffee is a popular beverage and highly cultivated crops worldwide, and it is the largest consumed and traded commodity globally (Murthy and Naidu, 2012). About 80 countries worldwide were cultivated coffee plantation and contributed to the world business sector (Murthy and Naidu, 2012). More than 8.2 million tons of coffees are produced in 2010/2011 in the world (USDA, 2011). Globally around 2250 million cups of coffee are drunk every day (USDA, 2011). More than $90 \%$ of coffee production occurs in developing countries, whereas utilization is mostly in industrialized economies (Ponte, 2002). Ethiopia is the beginning of highland coffee which is internationally traded coffee (Schmitt, 2006). Coffee plays a crucial role in the incomes of the country population directly or indirectly (LCM, 2000). More than 1249 wet coffee processing plants were constructed near water bodies in Ethiopia. The industries need a lot of water to wash wet coffee bean, removing the pulp and the mucilage (Dadi et al., 2018). The wastewater discharges from the process of wet coffee plants are directly into nearby streams and rivers without treatment, and it is the cause of environmental pollution and human health (Beyene et al., 2014). Due to the problems, it is essential to treat wastewater discharge from wet coffee processing plant by using aeration with constructed wetland treatment before effluent to an environment. The pollutant parameters were characterized from October 1, 2020, to February 30, 2021, at Jimma University, Environmental Health Science and Technology Laboratory, Ethiopia.

\section{Materials and methods}

\subsection{Sample collection}

Cyperus-ustulatus plant (P1) and, Typha-latifolia plant (P2) are local plants that grow wherever Ethiopia.The nurseries of those local plants gathered from wetland areas of the Jimma zone. The wet coffee processing wastewater samples collected from Gera, Mana, Goma and Limu-Kosa woredas using plastic containers (polyethene jerrican) of 20 L capacity, Jimma Zone, Oromia, Ethiopia. The collected wastewaters were mixed in equal proportion (1:1 ratio) in 
the $100 \mathrm{~L}$ storage container and then combined with tap water according to their proportions for experiments.

\subsection{Physco-chemical characterizations of wastewater}

The physio-chemical characteristics of wastewater used for the experiments are shown in Table 1 . The wastewater samples were analyzed in the laboratory of the Department of Environmental Health Sciences, Jimma University, Ethiopia, from October 2020 to February 2021. The wastewater was characterized as per the Standard procedure (APHA, 1992). Characterization of wet coffee processing wastewater was carried in terms of total solids, biological oxygen demand, chemical oxygen demand, $\mathrm{pH}$, and nutrients.

\subsection{Experimental design procedure}

\subsubsection{Combination of wastewater}

Wet coffee processing wastewater collected from four district and mixed in equal proportion in the $100 \mathrm{~L}$ storage plastic container then after it is combined with tap water as the following proportion: $\mathrm{T} 1=100 \% \mathrm{WCPWW}+0 \%$ Tap water; $\mathrm{T} 2=75 \% \mathrm{WCPWW}+25 \%$ Tap water; T3= 50\% WCPWW + 50\% Tap water; T4= 25\% WCPWW + 75\% Tap water; T5 $=0 \%$ WCPWW $+100 \%$ Tap water. The combined wastewaters were characterised before used for wetland/Cyperus-ustulatus plant and Typha-latifolia plant experimental process.

\subsubsection{Constructed wetland}

The concrete stages were constructed before the experiment started, then collect the plastic boxes their dimension was $0.27 \mathrm{~m}$ depth, $0.20 \mathrm{~m}$ width, and $0.45 \mathrm{~m}$ long. The box was filled with at bottom, centre and top by gravel, sand, and soil. All boxes by randomizing block design method arranged on the constructed concrete stage; the nurseries of $\mathrm{P} 1$ and $\mathrm{P} 2$ growth upon the box of each treatment and control (without plant) was proposed for each treatment under greenhouse. The treatment setup was adjusted the inflow rates with $0.0375 \mathrm{~L} \mathrm{~min}^{-1}$ for P1, P2 and controls for 21 days of irrigation. Analysis of the treated wastewater by standards procedure (APHA, 1992) and calculated residence time using Eq. (1) is given below (Crites et al., 1994; Selvamurugan et al., 2010).

$$
\text { Residence time }=\frac{\text { Plant bed volume } \times \text { Porosity }}{\text { combined wastewater flow }}
$$

\subsection{Analysis}

\subsubsection{Data analysis}

Total solid, Nutrients and Organic load treatment capacity of combined wastewater using constructed wetland treatment were calculated using Eq. (2) is given below (Clara et al., 2005; Zerihun et al., 2018).

$$
\text { Treated Capacity of WL }(\%)=\frac{\left(C_{1}-C_{E}\right) \times 100}{C_{1}}
$$

Where: $C_{1}=$ Influent concentration of combined wastewater $\left(\mathrm{mg} \mathrm{L}^{-1}\right)$ and $C_{E}=$ Effluent concentration of treated wastewater $\left(\mathrm{mg} \mathrm{L}^{-1}\right)$

\subsubsection{X-Ray Diffraction (XRD) and fourier transform infrared analysis}

XRD (Model No. XRD-7000, Shangai Drawell Scientific Instrument Co Ltd, China) analyses original soil and after treatment soil structure. Functional groups of the original soil and after FTIR analyzed treatment soil (Model No. FTIRL1600300, Spectrum Two LITA, Llantrisant, UK).

\section{Results and discussion}

\subsection{Description of the study area}

The study was carried out in four weredas (district): LimuKosa, Mana, Gera, and Gomma. Out of the wereda, three of them, such as Mana, Goma, and Gera districts, located $19 \mathrm{~km}, 55 \mathrm{~km}$ and $75 \mathrm{~km}$ away from Jimma town in the southwest direction. Limu-Kosa district wet coffee processing plant location far from Jimma town $25 \mathrm{~km}$ in the west direction. Jimma town is located $352 \mathrm{~km}$ from A. A. in South-west Ethiopia. In the zone established greater than 250 wet coffee processing industries (WCPI) these four districts. It is indicated that these four weredas cover greater than $75 \%$ WCPI from the Jimma zone. These wet coffee processing plants discharge their wastewater into near water bodies without treat by using eco-friendly technology. These four weredas (districts) and Jimma town are lying between Latitude $7^{0} 33^{\prime}$ (Gera district) up to $8^{0} 26^{\prime}$ (Limu-Kosa district) North and Longitude $35^{\circ} 91^{\prime}$ (Gera district) up to37 $36^{\prime}$ (Limu-Kosa district)east and with an elevation of $1643 \mathrm{~m}$ (Mana district) up to $1967 \mathrm{~m}$ (Gera district) above sea level. The mean minimum and maximum annual temperature range between $20^{\circ} \mathrm{C}$ and $32^{\circ} \mathrm{C}$, respectively (Figure 1 ).

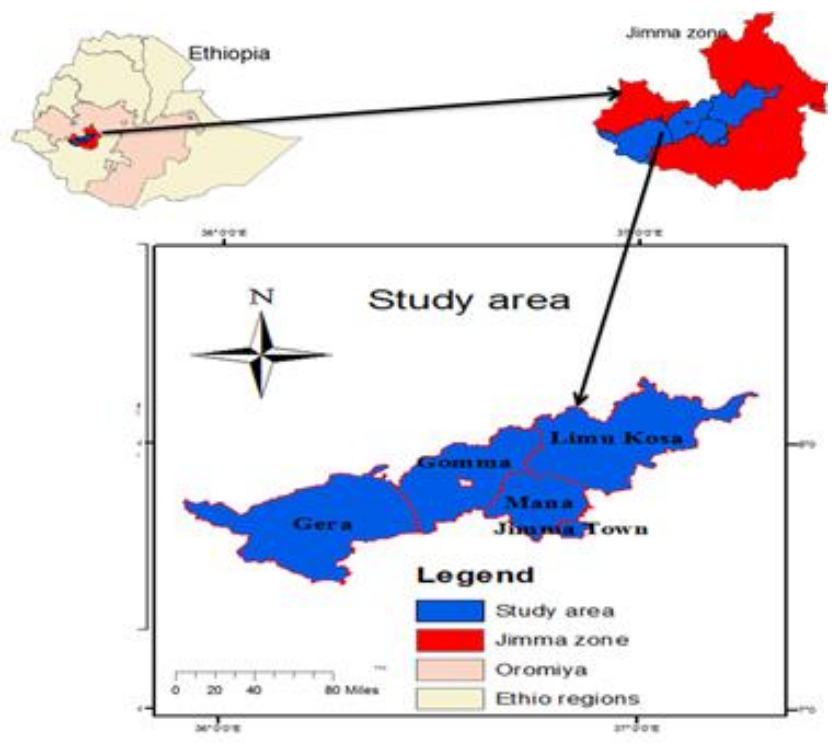

Figure 1. Location map of Gera, Gomma, Mana, Limu-Kosa districts and Jimma town.

\subsection{Characteristics of wastewater}

Characteristics of raw wastewater (Table 1) were made in triplicate for each parameter. The laboratory analysis was analysed using the followed instruments; TDS and TSS by gravimetric method, BOD by azide modification of the Winkler method, TN, TP and COD colourimetrically by DR $5000^{\mathrm{TM}}$ UV-Vis spectrophotometer by using $\mathrm{HACH}$ 
instruction. Due to pectin and tannin's degradation results, the colour of WCPWW was changed (Mendoza and Rivera, 1998). The $\mathrm{pH}$ value was from 3.09 to 4.88 it indicates that the sugars changed to alcohol and $\mathrm{CO}_{2}$. Then the alcohol is changed to acetic acid by the process of fermentation (Calvert, 1997). The presences of total solids were high due to the biodegradable nature of wastewater. The $\mathrm{BOD}_{5}$ value was from 3172 to $4432 \mathrm{mg} \mathrm{L}^{-1}$, which shows that organic

Table 1. Physico-chemical analysis of wet coffee processing plant raw wastewater (WCPPRWW) and after the combination of tap-water

\begin{tabular}{cccccccc}
\hline \multirow{2}{*}{ No. } & \multirow{2}{*}{ Parameters } & \multirow{2}{*}{ Raw CWW } & \multicolumn{2}{c}{ The initial concentration of CWW after combination with tap water } \\
\cline { 3 - 7 } & & & T1 & T2 & T3 & \multicolumn{1}{c}{ T4 } & T5 \\
\hline 1 & Colour $(\mathrm{cu})$ & $602 \pm 43$ & $580 \pm 29$ & $462 \pm 21$ & $410 \pm 24$ & $375 \pm 32$ & $12 \pm 3$ \\
\hline 2 & $\mathrm{pH}$ & $3.50 \pm 41$ & $3.83 \pm 0.15$ & $4.14 \pm 0.67$ & $4.68 \pm 0.76$ & $5.13 \pm 0.61$ & $6.15 \pm 0.73$ \\
\hline 3 & $\mathrm{EC}(\mu \mathrm{s} / \mathrm{cm})$ & $735 \pm 50$ & $644 \pm 65$ & $527 \pm 63$ & $401 \pm 102$ & $269 \pm 68$ & $142 \pm 43$ \\
\hline 4 & $\mathrm{TSS}(\mathrm{mg} / \mathrm{L})$ & $2907 \pm 68$ & $2857 \pm 58$ & $1566 \pm 79$ & $912 \pm 47$ & $501 \pm 38$ & $21 \pm 7$ \\
\hline 5 & $\mathrm{TDS}(\mathrm{mg} / \mathrm{L})$ & $1940 \pm 69$ & $1825 \pm 72$ & $1585 \pm 47$ & $820 \pm 38$ & $510 \pm 43$ & $125 \pm 26$ \\
\hline 6 & $\mathrm{TS}(\mathrm{mg} / \mathrm{L})$ & $3820 \pm 69$ & $3650 \pm 52$ & $2290 \pm 76$ & $1109 \pm 65$ & $501 \pm 98$ & $109 \pm 31$ \\
\hline 7 & Turbidity(NTU) & $729 \pm 21$ & $511 \pm 68$ & $249 \pm 14$ & $181 \pm 26$ & $97 \pm 21$ & $3.5 \pm 0.79$ \\
\hline 8 & $\mathrm{DO}(\mathrm{mg} / \mathrm{L})$ & $1.66 \pm 0.16$ & $1.35 \pm 0.14$ & $1.33 \pm 0.13$ & $1.29 \pm 0.15$ & $1.03 \pm 0.16$ & $0.79 \pm 0.04$ \\
\hline 9 & $\mathrm{BOD} 5(\mathrm{mg} / \mathrm{L})$ & $4322 \pm 110$ & $4023 \pm 90$ & $3244 \pm 62$ & $2277 \pm 80$ & $484 \pm 64$ & $2.4 \pm 0.62$ \\
\hline 10 & $\mathrm{COD}(\mathrm{mg} / \mathrm{L})$ & $7612 \pm 43$ & $7224 \pm 49$ & $5511 \pm 68$ & $3554 \pm 110$ & $1524 \pm 28$ & $113 \pm 32$ \\
\hline 11 & $\mathrm{BOD}: \mathrm{COD}$ ratio & $0.57 \pm 0.01$ & $0.56 \pm 0.01$ & $0.58 \pm 0.01$ & $0.65 \pm 0.01$ & $0.32 \pm 0.01$ & $0.022 \pm 0.01$ \\
\hline 12 & $\mathrm{NH} 4-\mathrm{N}(\mathrm{mg} / \mathrm{L})$ & $10.78 \pm 0.32$ & $7.99 \pm 0.13$ & $5.94 \pm 0.34$ & $4.8 \pm 0.16$ & $3.07 \pm 0.08$ & $0.47 \pm 0.11$ \\
\hline 13 & $\mathrm{NO}-\mathrm{N}(\mathrm{mg} / \mathrm{L})$ & $260 \pm 30$ & $230 \pm 40$ & $193 \pm 35$ & $122 \pm 27$ & $61 \pm 14$ & $1.75 \pm 0.05$ \\
\hline 14 & $\mathrm{PO43}(\mathrm{mg} / \mathrm{L})$ & $10.48 \pm 0.4$ & $8.15 \pm 0.9$ & $5.13 \pm 0.8$ & $3.3 \pm 0.8$ & $1.33 \pm 0.8$ & $0.003 \pm 0.001$ \\
\hline & & & & & &
\end{tabular}

\subsection{Treatment of wet coffee processing wastewater}

\subsubsection{Treatment of coffee wastewater (CWW) using} constructed wetland (CW)

The CW was processed at various hydraulic retention times of different wastewater concentrations such as T1, T2, T3, $\mathrm{T} 4$ and $\mathrm{T} 5$ in Table 2. The CW was irrigated with combined CWW containing BOD 5 and COD amount from 284 to 4322 and 1524 to $7224 \mathrm{mg} \mathrm{L}^{-1}$. The TS value from 501 to $3820 \mathrm{mg}$ $\mathrm{L}^{-1}$. The $\mathrm{pH}$ value ranges from 3.83 to 5.13. At T3 concentration with the Typha-latifolia plant after 21 days irrigated, the removal capacity for COD and $\mathrm{BOD}_{5}$ was $95 \%$ and $96 \%$, respectively. The experiment results achieved the highest removal capacity of TS by the Typha-latifolia Plant at $74 \%$. The $\mathrm{pH}$ of treated effluent from Typha-latifolia ranged from 6.51 to 6.85 . load amounts were high. According to Shanmukhappa et al. (1998) studied that BOD samount $10,000-12,000 \mathrm{mg} \mathrm{L}^{-1}$ in CPWW. Due to the low degrading compound $f$ COD amount (6070-7655 $\mathrm{mg} \mathrm{L}^{-1}$ ) in the WCPWW. According to Haddis and Devi (2008) in Ethiopia and Mburu et al. (1994) in Kenya, the finding of their study agreed with the result of this study.
The results show increasing the CW treatment efficiency in combination T2 and T3 with Typha-latiolia plant wetland treatment and T3 combination performed with higher efficiency than T2 combination Typha-latiolia plant. But, the amount of removal efficiency was different with the mixture. The difference in combination wastewater with tap water amount using Typha-latiolia plant with constructed wetland efficiency for the three parameters (COD, $\mathrm{BOD}_{5}$ and $\left.\mathrm{TS}\right)$ was the smallest amount. The coffee wastewater combination (T2, T3 and T4) did not show decreasing and increasing pattern, but at T3, treatment was good, according to Table 2 result shows (COD $=195 \mathrm{mg}$ $\left.\mathrm{L}^{-1}\right)$. It is agreed with the Central Pollution Control Board standards because of COD of $<250 \mathrm{mg} \mathrm{L}^{-1}$ (Selvamurugan, 2010).

Table 2. Removal capacity of various concentrations using constructed wetland with Typha-latiolia plant

\begin{tabular}{|c|c|c|c|c|c|c|c|c|c|c|}
\hline \multirow{2}{*}{$\begin{array}{c}\text { Treatments } \\
\text { CWW with } \\
\text { TW }\end{array}$} & \multicolumn{2}{|c|}{$\mathrm{TS}$ (mg/ L) } & \multicolumn{2}{|c|}{$\mathrm{BOD}_{5}(\mathrm{mg} / \mathrm{L})$} & \multicolumn{2}{|c|}{$\operatorname{COD}(\mathrm{mg} / \mathrm{L})$} & \multicolumn{2}{|c|}{$\mathrm{NO}_{3}-\mathrm{N}(\mathrm{mg} / \mathrm{L})$} & \multicolumn{2}{|c|}{$\mathrm{PO}_{4}{ }^{3}(\mathrm{mg} / \mathrm{L})$} \\
\hline & Initial & Final (\%) & Initial & Final (\%) & Initial & Final (\%) & Initial & Final (\%) & Initial & Final (\%) \\
\hline $\mathrm{T} 1$ & 3650 & $1312(64)$ & 4023 & $737(86)$ & 7224 & $1564(78)$ & 230 & $147(31)$ & 8.15 & $2.2(73)$ \\
\hline $\mathrm{T} 2$ & 2290 & $1268(47)$ & 3244 & $405(87)$ & 5511 & $923(83)$ & 193 & $105(45)$ & 5.13 & $1.7(67)$ \\
\hline T3 & 1109 & $265(76)$ & 2277 & $82(96)$ & 3554 & $195(95)$ & 122 & $15(88)$ & 3.3 & $0.2(94)$ \\
\hline $\mathrm{T} 4$ & 500 & $489(2)$ & 484 & $121(75)$ & 1524 & $235(85)$ & 61 & $36(41)$ & 1.33 & $0.5(62)$ \\
\hline T5 & 109 & $213(-95)$ & 2.4 & $3.14(-31)$ & 113 & $218(-93)$ & 1.75 & $2.53(-45)$ & 0.003 & $0.01(-32)$ \\
\hline
\end{tabular}

\subsubsection{Combined wastewater treatment}

The raw CPWW had contained; $\mathrm{pH}, \mathrm{EC}, \mathrm{BOD}_{5}, \mathrm{COD}$ and TS of supply were $3.5,735 \mu \mathrm{s} . \mathrm{cm}^{-1}, 4322,7612$ and $3820 \mathrm{mg}$ $\mathrm{L}^{-1}$, respectively. The removal efficiency of $\mathrm{BOD}_{5}$ and $\mathrm{COD}$ was $96 \%$ and $95 \%$, respectively; in a combination of $50 \%$ coffee wastewater and $50 \%$ tap water irrigated with 21 


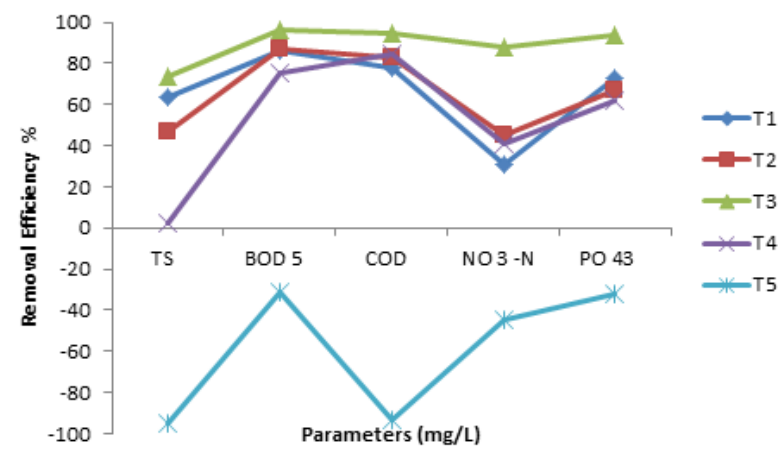

Figure 2. Effect of concentration on the efficiency of Constructed wetland in the removal of $\mathrm{TS}, \mathrm{BOD}_{5}, \mathrm{COD}, \mathrm{NO}_{3}-\mathrm{N}$ and $\mathrm{PO}_{4}{ }^{3}$.

\subsubsection{Constructed wetland treatment of WCPWW}

The combined CPWW with T1, T2, T3, T4 and T5 were irrigated for Cyperus-ustulatus (P1), Typha-latifolia (P2) and Control without plants for 21 days. The effluents result indicated that (in Table 2) from the two plants, Typhalatifolia remove $96 \%$ of $\mathrm{BOD}_{5}$ in a combination of coffee wastewater $(50 \%)$ and tap water $(50 \%)$ after 21 days of irrigation. Cyperus-ustulatus followed it with $95 \% \mathrm{BOD}_{5}$ removal combined with T3 combination WCPWW. A similar study indicated that the removal capacity of BOD 5 was $75 \%$ with the wetland process (Cooper, 1993; Vymazal, 2005).
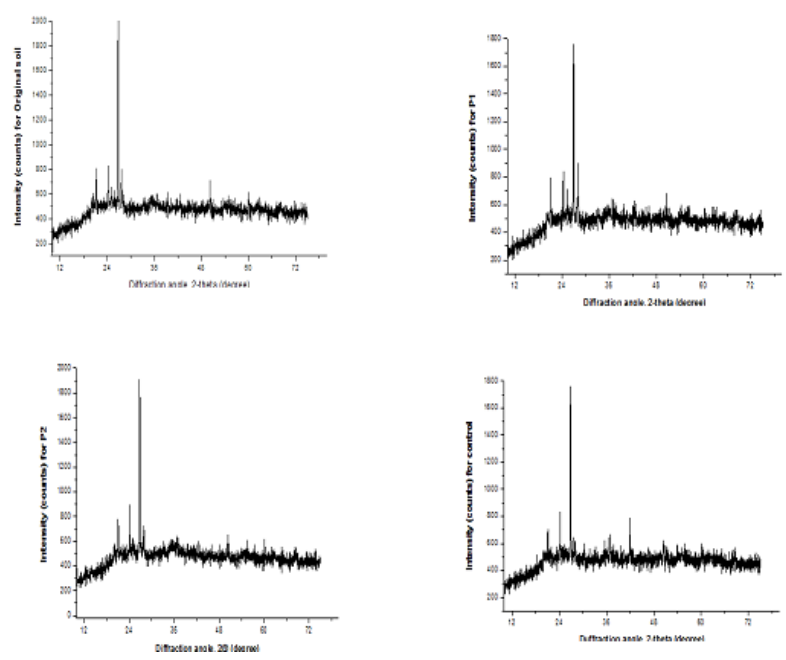

Figure 3. XRD analysis of before treated dried original soil, after treated dried soil from Cyperus-ustulatus plant (P1) in CW,

Typha-latifolia plant (P2) in CW, and without plant (control) in CW, respectively.

The TS removal efficiency of $74 \%$ was combined $50 \%$ WW and $50 \%$ TW treated with Typha-latifolia. It was followed by $54 \%$ of TS removal in a combined $50 \%$ WW and $50 \%$ TW CPWW treated with Cyperus-ustulatus. According to Sapkota and Bavor (1994), the removal capacity of total suspended solids is between $30 \%$ to $86 \%$ in the gravelbased sub surface flow process.

\subsection{X-ray diffraction (XRD) and fourier transform infrared (FTIR) spectroscopy analysis}

\subsubsection{X-ray diffraction (XRD) analysis}

The XRD analysis result is shown in Figure 3 . The XRD analysis of the original soil before treatment and the sludge after treatment with various combination of coffee wastewater with tap water in constructed wetland using both plants (Typha-latiolia and Cyperus-ustulatus) and control (without plant) shows that polymeric compounds present in the raw materials. All type of filling materials to constructed wetland system reveal diffuse peaks in the spectrum that peaks indicated the amorphous crystalline in nature and the soil contain metals (Ghosh et al., 2008). A few small humps were described in the original soil's range and treated soil without plants (control that indicated an amorphous phase.

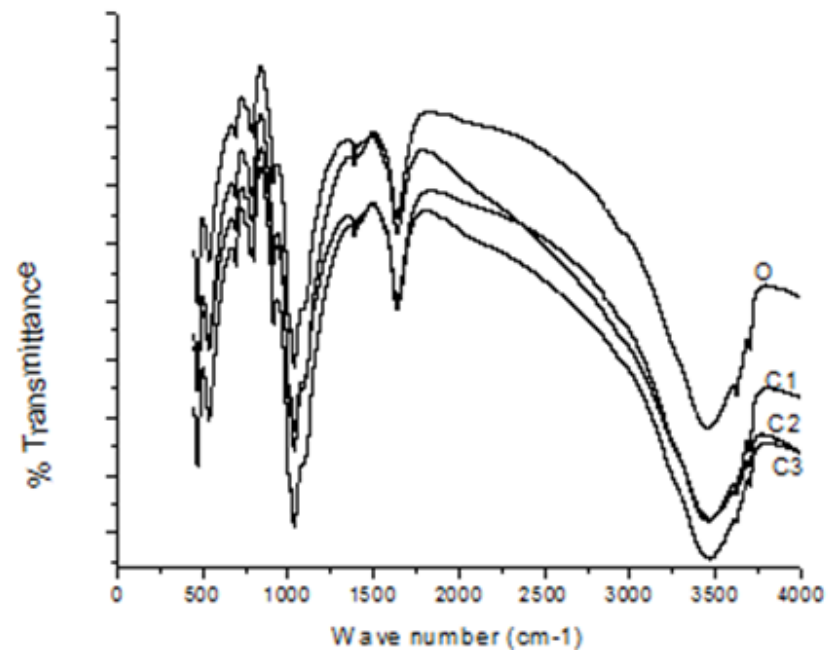

Figure 4. FTIR spectra soil (O) before treated dried original soil, (C1) after treated dried soil with Cyperus-ustulatus (P1), (C2) after treated dried soil with Typha-latifolia (P2), and (C3) after treated dried soil without plant (control).

\subsubsection{Fourier transform infrared spectroscopy (FT-IR) analysis}

The FT-IR spectra of original soil (Figure 4: 0) and after treated (Figure 4: C1, C2, and C3) with coffee wastewater was shown in Figure 4 . In the case of original soil before treated $(O)$ in Figure 4, it indicated that various peak represented different stretching such as $1100 \mathrm{~cm}^{-1}$ for $-\mathrm{OH}$, $3,400 \mathrm{~cm}^{-1}-\mathrm{CH}_{2}, 500 \mathrm{~cm}^{-1}$ for $\mathrm{C}=\mathrm{O}, 550 \mathrm{~cm}^{-1}$ for $\mathrm{C}=\mathrm{C}, 750$ $\mathrm{cm}^{-1}$ between $900 \mathrm{~cm}^{-1}$ for $\mathrm{C}=\mathrm{C}$ and $1400 \mathrm{~cm}^{-1}$ and $1750 \mathrm{~cm}^{-}$ ${ }^{1}$ for C-O (Colleen et al., 2011; Qu et al., 2010; Cruz et al., 2006 and Rao et al., 2007). The FT-IR spectrum of wastewater absorbent shows that in Figure 4. (C1) after treated dried soil with Cyperus-ustulatus (P1), (C2) after treated dried soil with Typha-latifolia (P2), and (C3) after treated dried soil without plant (control), shows that the peaks because of functional groups are a little affected in their intensity and position. It indicates that the wetland treatments absorption of wastewater on the surface of soil, sand and plants are with complexation or weak elecrtostatistic interaction and Van der Waals forces (Colleen et al., 2011; Qu et al., 2010; Cruz et al., 2006 and Rao et al., 2007).

\section{Conclusions}

The experimental result indicated that discharged wet coffee processing wastewater combined with tap-water treated locally available plants (Typha-latifolia and 
Cyperus-ustulatus) with constructed wetland treatment processes are technically viable eco-friendly technology. Removal capacity of Typha-latifolia plant with the combined $50 \%$ CWW and 50\% TW after irrigated 21 days the result indicated that the removal efficiency was Total Solid (74\%), COD (95\%), BOD $(96 \%), \mathrm{NO}_{3}-\mathrm{N}(88 \%)$, and $\mathrm{PO}_{4}{ }^{3}$ (94\%). From the result, it concluded that the combined wet coffee processing wastewater was appropriate for biological treatment. The discharged wastewater combined with tap-water treated by constructed wetland with Typha-latifolia and Cyperus-ustulatus plants were lowcost, affordable, technically viable and eco-friendly treatment technology.

\section{Acknowledgements}

The author would like to thank the Jimma University Institute of Technology, Ministry of Science and Higher Education, Ethiopia, and ExiST project (No. 51235, BMZ No. 201166305) funded by KfW (Germany) for their financial support. I am also thankful to the wet coffee processing industry owners, Prof. A. Venkata Ramayya, Mrs Saskia, Dr Adnew, Mr Zewudu and Mrs Meskerem, for their assistance during this Postdoctoral research.

\section{References}

APHA (1992). Standard Methods for the Examination of Water and Wastewater, 18th ed. American Public Health Association, Washington, USA.

Beyene A., Yemane D., Addis T., Assayie A. and Triest L. (2014). Experimental evaluation of anaerobic digestion for coffee wastewater treatment and its bio methane recovery potential. International Journal of Environmental Science and Technology, 11, 1881-1886.

Calvert C.K. (1997). The treatment of coffee processing wastewaters: the biogas option - a review and preliminary report. Coffee Industry Corporation Ltd., Papua New Guinea, p. 22.

Choudhury S., Rohella R., Manthan M. and Sahoo N. (1998). Decolourization of kraft paper mill effluent by white-rot fungi. Indian Journal of Microbiological, 38, 221-224.

Clara M., Kreuzinger N., Strain B., Gans O. and Kroiss H. (2005). The solids retention time a suitable design parameter to evaluate the capacity of wastewater treatment plants to remove micro pollutants. Water Resource, 39, 97-106.

Colleen G., Isabel C. and Escobar E. (2011). N-isopropyl acrylamide (NIPAAM) modified cellulose acetate ultrafiltration membranes. Journal of Membrane Science, 383, 272-279.

Cooper P.F. (1993). The use of reed bed systems to treat domestic sewage: The European design and operations guidelines for reed bed treatment systems. In: Moshiri G.A. (Ed.), Constructed Wetlands for Water Quality Improvement. Lewis Publishers, Boca Raton.

Crites R.W., Lekven C.C. and Beggs R.A. (1994). Constructed wetlands at Mesquites, Nevada. In: Proceedings of the ASCE Environmental Engineering Conference, Nevada, pp. 390-395.

Cruz M.P., Barbosa L.C., Maltha C.R., Gomide J.L. and Milanez A.F. (2006). Chemical Characterization of the pitch in Eucalyptus pulp and paper industry. Quimica Nova, 29, 459-466.

Dadi D., Mengistie E., Terefe G., Getahun, Haddis, Birke W., Beyene A., Luis P. and Bruggen B. (2018). Assessment of the quality of effluent of wet coffee processing wastewater and its influence on downstream water quality. Journal of Ecohydrology and Hydrobiology, 18, 201-211.

Ghosh D., Medhi C.R. and Purkait M.K. (2008). Treatment of fluoride-containing drinking water by electrocoagulation using monopolar and bipolar electrode connections. Chemosphere, 73, 1393-1400.

Haddis A. and Devi R. (2008). Effect of effluent generated from a coffee processing plant on the water bodies and human health in its vicinity. Journal of Hazardus Material, 152, 259262

LMC (2000). International Coffee Organization/Common Fund of Commodities Study of Marketing and Trading Policies and Systems in Selected Coffee Producing Countries. Ethiopia.

Mendoza R.B. and Rivera M.F. (1998). Startup of an anaerobic hybrid UASB/Filter reactor treating wastewater from a coffee processing plant, Anaerobe, 14, 219-225.

Murthy P.S. and Naidu M.M. (2012). Sustainable management of coffee industry by-products and value addition a review. Journal of Resource, Conservation and Recycling, 66, 45-58.

Ponte S. (2002). The latte revolution'? Regulation, markets and consumption in the global coffee chain. Journal of World Development, 30, 1099-1122.

Qu P., Tang H., Gao Y., Zhang L. and Wang S. (2010). Polyethersulfone composite membrane blended with cellulose fibrils. BioResources, 5, 2323-2336.

Rao P.S., Reddy K.V., Kalyani S. and Krishnaiah A. (2007). Comparative sorption of copper and nickel solutions by natural neem (Azadirachta indica) sawdust and acid-treated sawdust. Wood Science and Technology, 41, 427-442.

Sapkota D.P. and Bavor H.J. (1994). Gravel media filtration as a constructed wetland component for the reduction of suspended solids from maturation pond effluent. Water Sacience and Technology, 29, 55-66.

Schmitt C.B. (2006). Montana Rainforest with Wild Coffea Arabica in the Bonga Region: Plant Diversity. Wild Coffee Management and Implications for Conservation, Ethiopia.

Selvamurugan M., Doraisamy P. and Maheswari M. (2010). An integrated treatment system for coffee processing wastewater using anaerobic and aerobic process. Journal of Ecolological Engineering, 369, 1686-1690.

Shanmukhappa D.R., Ananda Alwar R.P. and Srinivasan C.S. (1998). Water pollution by coffee processing units and its abatement. Industrial Coffee, 10, 3-9.

USDA. (2011). World Markets and Trade: Coffee. United States Department of Agriculture, Foreign Agricultural Service, Office of Global Analysis.

Vymazal J. (2005). Horizontal sub-surface flow and hybrid constructed wetland systems for wastewater treatment. Journal of Ecological Engineering, 25, 478-490.

Zerihun A., Tilahun S., Cristina T. and Fekadu F. (2018). Removal of $\mathrm{Cr}(\mathrm{VI})$ from contaminated water using soil rich in kaoliniteferrinatrite, coffee husk ash and soil rich in kaolinite-goethite: characteristic, isotherm and kinetic study. Desalination and Water Treatment, 105, 250-254. 